\title{
AIS Transactions on Human-Computer Interaction
}

Volume 7 | Issue 3

Article 3

2015

\section{Examining the Persuasive Potential of Web-based Health Behavior Change Support Systems}

Tuomas Lehto

University of Oulu, tuomas.lehto@gmail.com

Harri Oinas-Kukkonen

University of Oulu, harri.oinas-kukkonen@oulu.fi

Follow this and additional works at: https://aisel.aisnet.org/thci

\section{Recommended Citation}

Lehto, T., \& Oinas-Kukkonen, H. (2015). Examining the Persuasive Potential of Web-based Health Behavior Change Support Systems. AIS Transactions on Human-Computer Interaction, 7(3), 126-140. Retrieved from https://aisel.aisnet.org/thci/vol7/iss3/3

DOI:

This material is brought to you by the AIS Journals at AIS Electronic Library (AISeL). It has been accepted for inclusion in AIS Transactions on Human-Computer Interaction by an authorized administrator of AIS Electronic Library (AISeL). For more information, please contact elibrary@aisnet.org. 


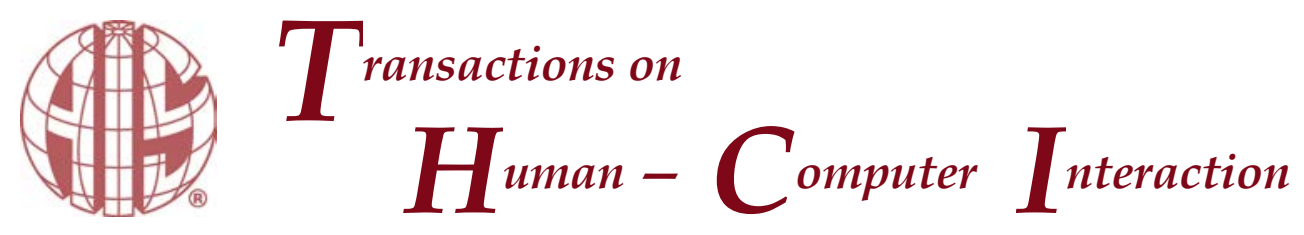

Research Paper

ISSN: 1944-3900

\title{
Examining the Persuasive Potential of Web-based Health Behavior Change Support Systems
}

\author{
Special Issue: HCI in Health and Wellness
}

\author{
Tuomas Lehto \\ Oulu Advanced Research on Service and Information Systems \\ Faculty of Information Technology and Electrical Engineering \\ University of Oulu \\ tuomas.lehto@gmail.com
}

\author{
Harri Oinas-Kukkonen \\ Oulu Advanced Research on Service and Information Systems \\ Faculty of Information Technology and Electrical Engineering \\ University of Oulu \\ Harri.oinas-kukkonen@oulu.fi
}

Abstract:

Understanding the persuasive potential of systems to support behavior change is increasingly important. If systems are not designed properly, their persuasive potential is not fulfilled. Previous research has shown that persuasive system design has a significant impact on adherence. Moreover, persuasive system features are likely to be advantageous in boosting effective user engagement with the technology and keeping the users motivated in their endeavors. In this study, we identify persuasive system features used in a selection of Web-based health behavior change support systems targeting excessive alcohol use and weight loss. We conducted en expert-based evaluation using the persuasive systems design model as a lens to view the twelve selected Web-based systems. The evaluation included a hands-on approach in which we used the systems for at least one month each and evaluated in terms of four categories: primary task support, computer-human dialogue support, system credibility, and social support. The results suggest that the systems harness a decent number of persuasive features. However, they had room for improvement (e.g., in terms of tailoring). Further research is needed to increase our understanding of how and under what conditions specific persuasive system features, either in isolation or collectively, lead to positive health outcomes in behavior change support systems across diverse contexts and populations. This study adds to the body of knowledge on designing persuasive health behavior change support systems.

Keywords: Health, Behavior Change Support Systems, Web-based, Evaluation, Persuasive Systems Design. 


\section{Introduction}

Changing people's behavior is at the heart of health promotion. In the past decade, using technologies to persuade, motivate, and activate individuals to change their health behavior has been a swiftly expanding field of research. Using the Internet for delivering health behavior change interventions has been especially prevalent. Applications and systems for preventing, assessing, and treating conditions such as alcohol problems (Bewick et al., 2008), depression (van Straten, Cuijpers, \& Smits, 2008), diabetes (Tate, Jackvony, \& Wing, 2003), obesity (Harvey-Berino et al., 2010), physical inactivity (Hurling et al., 2007), and smoking (Shahab \& McEwen, 2009) have been tested in numerous controlled trials. These Webbased automated health behavior change interventions potentially have high reach and a low cost. Recent comprehensive meta-analyses provide support for their effectiveness in increasing users' knowledge and awareness and changing their attitudes and behavior in the health promotion area (Portnoy, ScottSheldon, Johnson, \& Carey, 2008; Webb, Joseph, Yardley, \& Michie, 2010).

Various terms have emerged to describe technology-based interventions for mental and physical health purposes: cybertherapy, digital therapy, e-therapy, e-health, e-interventions, digital interventions, Internet interventions, computer-mediated interventions, online therapy, and Web-based therapy, among others (cf. Barak, Klein, \& Proudfoot, 2009). However, a consensus on the terminology has not yet been reached. Barak et al. $(2009$, p. 5) defines a Web-based intervention as a primarily self-guided intervention program that is executed via a prescriptive online program, operated through a website, and used by consumers seeking health- and mental-health related assistance; the intervention program itself attempts to create positive change and or improve/enhance knowledge, awareness, and understanding via providing sound health-related material and interactive Web-based components.

These Web-based interventions are examples of a larger phenomenon known as behavior change support systems (BCSS) (Oinas-Kukkonen, 2013). Oinas-Kukkonen (2013) defines a BCSS as "a sociotechnical information system with psychological and behavioral outcomes designed to form, alter or reinforce attitudes, behaviors or an act of complying without using coercion or deception" (p. 1225).

A major challenge in Web-based interventions is that participant attrition is generally high (typically more than 25\%), and, among the retained participants, engagement rates usually decline remarkably over time (Bennett \& Glasgow, 2009; Eysenbach, 2005; Neve, Morgan, Jones, \& Collins, 2009). As reducing attrition and increasing website use would likely enhance (any) intervention success, designing, implementing, and evaluating features that participants find attractive and captivating should clearly be a priority (Krukowski, Harvey-Berino, Ashikaga, Thomas, \& Micco, 2008).

Sillence and Briggs (2007) and Silence, Briggs, Harris, and Fishwick (2006) suggest that design issues are not superficial; instead, they have important implications: the quality of the content becomes insignificant if bad design is an obstacle for users. Hardiker and Grant (2010, p. 10) emphasize that:

...there should be continued focus on appropriate design and content of e-health services. Services should aim to provide understandable, relevant and trustworthy content to a wide variety of potential users and in a way that is straightforward to use and that fits with day-to-day life.

Kelders, Kok, Ossebaard, and Van Gemert-Pijnen (2012) conducted a systematic review of 83 Webbased health interventions. Through a multiple regression analysis, they investigated whether intervention characteristics and persuasive system features (Oinas-Kukkonen \& Harjumaa, 2009) could predict adherence. They found that, by using these variables, they could explain a substantial amount of variance in adherence. However, they largely relied on textual descriptions of the Web-based interventions provided.

In this study, we examine the persuasive potential of health behavior change support systems by investigating the actual systems. We apply the persuasive systems design (PSD) model (Oinas-Kukkonen \& Harjumaa, 2009) to extract and analyze persuasive system features found in the sample of BCSS.

\section{Background}

Persuasive technology is a relatively new area of research. Fogg (2003) envisioned the potential of pervasive computing technologies to induce and influence people to change their attitudes and behaviors. His work conceptualized persuasive technology as a research discipline encompassing human psychology, persuasion, and information technology. 
Oinas-Kukkonen (2013) describes behavior change support systems as a primary focus of research in the area of persuasive technologies. One could implement a BCSS to impact individual-, organizational-, or societal-level attitudes, behaviors, and values. BCSS are persuasive systems by nature in that they employ computer-human persuasion and/or computer-mediated persuasion. In computer-human persuasion, the persuader is the computer software specifically designed with the intent to affect users' behaviors. Computer-human persuasion does not require a human interlocutor, whereas computermediated persuasion means that people are persuading others through, for example, email, instant messages, or social network platforms. Briñol and Petty (2009, p. 71) describe persuasion as follows:

In the typical situation in which persuasion is possible, a person or a group of people (i.e., the recipient) receives an intervention (e.g., a persuasive message) from another individual or group (i.e., the source) in a particular setting (i.e., the context).

Successful persuasion occurs when the target of change (e.g., attitudes, beliefs) is modified into the desired direction (Briñol \& Petty, 2009). We can consider persuasion on the Web as either computerhuman or computer-mediated persuasion.

Designing systems that aim to change behavior requires a thorough understanding of the problem domain, the underpinning theories, and strategies of persuasive systems design. Usually, an interdisciplinary team of professionals is called for the design process. The team might comprise, for example, healthcare professionals, psychologists, computer scientists, statisticians, and marketeers. Consolvo, McDonald, and Landay (2009) underscore that, if the technology intended to foster long-term behavior change is designed poorly and without a principal design approach, users will likely abandon it. Kreps and Neuhauser (2010) identify four main directions for designing e-health interventions to attain their full promise for promoting health. According to them, e-health interventions must (1) be interactive, encouraging, and involving; (2) be effective, transparent, and interoperable; (3) be dynamic and personally engaging; and (4) have high reach and adaptability (Kreps \& Neuhauser, 2010). Glanz and Bishop (2010) advocate creativity. In their view, interventions should be "as entertaining and engaging as the other activities with which they compete" (p. 412). Sillence and Briggs (2007) found out what people want from health advice websites: (1) a combination of medical and informal expert opinion, (2) an explanation of the explicit motivations behind the website, (3) information and guidance that is clear and uncomplicated; (4) tailored information and advice; and (5) an easy-to-use website.

According to Oinas-Kukkonen (2010), many design issues are general software design issues rather than issues specifically related to behavior change support systems. These design issues include, but are not limited to, ease of access, information quality, simplicity, convenience, attractiveness, number of errors, responsiveness, user experience, and user loyalty.

In this study, we investigate the persuasive system features on a selection of representative Web-based behavior change support systems.

\section{Research Setting}

\subsection{Persuasive Systems Design (PSD) Model}

Oinas-Kukkonen and Harjumaa $(2008,2009)$ have conceptualized a framework, known as the PSD model, for designing and evaluating persuasive systems. The PSD model builds on multiple theoretical constructs, such as goal-setting theory (Locke \& Latham, 2002), the elaboration likelihood model (Petty \& Cacioppo, 1986), and the theory of reasoned action/planned behavior (Ajzen, 1991), and it uses persuasive technology techniques that Fogg (2003), and others define. The PSD model describes a wide range of design features for BCSS, which can be subsumed under the four categories of primary task, dialogue, credibility, and social support features. The PSD model can be used as a tool by designers and intervention developers and as a framework for understanding and interpreting users' needs and how these needs can be implemented. Oinas-Kukkonen and Harjumaa (2009) describe the PSD model in detail.

In this study, we focus on the persuasive system features. In the PSD model, the categories for persuasive system principles are primary task support (supporting the user's primary task and goals), computer-human dialogue support (reinforcing the interaction between the user and the system), perceived credibility, and social support and influence (the system motivates users by leveraging social features). We discuss and exemplify the persuasive system design features in Section 5. 


\subsection{Sample Selection}

We gathered a brief but representative list of Web-based health behavior change support systems targeting alcohol misuse and weight loss. We chose those two particular problem domains since they matched our funded research project on digital interventions. Evidently, both domains are significant in terms of public health.

Even though we extensively searched for relevant papers and systems, we do not consider this method to be systematic or exhaustive. For instance, the search phrase "weight loss" yields over 200 million hits on Google alone. Moreover, going through all possible combinations and variations for search terms is practically impossible and will only lead to highly redundant search results. However, we did not limit ourselves to operate solely based on search engines; we also searched relevant literature to find the intervention websites that fell in our scope. As such, we searched databases, such as EBSCOhost, Google Scholar, ISI Web of Knowledge, PubMed, and Scopus. Table 1 presents our selection process and the selected Web-based BCSS. One could describe the selected sample of websites as a convenience sample.

Table 1. Selection of the Web-based Behavior Change Support Systems

\begin{tabular}{|c|c|c|c|c|}
\hline Domain & Search period & $\begin{array}{l}\text { Search term } \\
\text { examples }\end{array}$ & Inclusion criteria & Selected Web-based BCSS \\
\hline $\begin{array}{c}\text { Alcohol } \\
\text { abuse }\end{array}$ & $\begin{array}{c}\text { November } \\
\text { 2008-January } \\
2009\end{array}$ & $\begin{array}{l}\text { Alcohol, help, stop, } \\
\text { quit, recovery, drink, } \\
\text { consumption, } \\
\text { abstinence, } \\
\text { intervention, addiction, } \\
\text { dependence, Web, } \\
\text { Internet, online, self- } \\
\text { help }\end{array}$ & $\begin{array}{l}\text { The website had to be in } \\
\text { English, Finnish, or } \\
\text { Swedish; free of charge; } \\
\text { require registration; } \\
\text { accept international } \\
\text { users; and provide } \\
\text { extensive interactivity. }\end{array}$ & $\begin{array}{l}\text { Alcohol Help Center } 2.0 \text { (A1) } \\
\text { www.alcoholhelpcenter.net } \\
\text { Control Your Drinking Online (A2) } \\
\text { www.acar.net.au/online.asp } \\
\text { Down Your Drink (A3) } \\
\text { www.downyourdrink.org.uk } \\
\text { Sober24 (A4) } \\
\text { www.sober24.com } \\
\text { Alkoholhjälpen (A5) } \\
\text { www.alkoholhjalpen.se } \\
\text { Jeppe Juomapäiväkirja (A6) } \\
\text { www.paihdelinkki.fi/jeppe/index.php }\end{array}$ \\
\hline $\begin{array}{c}\text { Weight loss } \\
\text { and weight } \\
\text { management }\end{array}$ & $\begin{array}{c}\text { December } \\
\text { 2009-January } \\
2010\end{array}$ & $\begin{array}{l}\text { Weight, loss, control, } \\
\text { diet, nutrition, obesity, } \\
\text { intervention, Web, } \\
\text { Internet, online, self- } \\
\text { help }\end{array}$ & $\begin{array}{l}\text { The website had to be in } \\
\text { English; free of charge; } \\
\text { require registration; } \\
\text { accept international } \\
\text { users; and provide } \\
\text { extensive interactivity. }\end{array}$ & $\begin{array}{l}\text { Calorie Count (W1) } \\
\text { www.caloriecount.about.com } \\
\text { CalorieKing (W2) } \\
\text { www.calorieking.com } \\
\text { Diet.com (W3) } \\
\text { www.diet.com } \\
\text { ObesityHelp (W4) } \\
\text { www.obesityhelp.com } \\
\text { Project Weight Loss (W5) } \\
\text { www.projectweightloss.com } \\
\text { WebMD Healthy Eating and Diet } \\
\text { Center (W6) } \\
\text { www.webmd.com/diet/ }\end{array}$ \\
\hline
\end{tabular}

We evaluated the BCSS based on the principles for persuasive system content and functionality presented in the PSD model (Oinas-Kukkonen \& Harjumaa, 2009). The PSD model does not claim the existence of a relationship between the number of features implemented per se and the overall effect of a BCSS or its persuasiveness. However, in their recent meta-analysis, Webb et al. (2010) found that interventions employing more behavior-change techniques commonly demonstrated larger effects than 
those using fewer techniques. However, we do not compare the BCSS against each other since they vary greatly in terms of complexity, content, and quality; rather, we demonstrate this diversity and pinpoint the possible mutual and individual highlights/shortcomings in persuasive system features on the BCSS under inspection to study their persuasive potential.

\section{Data Abstraction}

Overall, we thoroughly examined the content, information, structure, and functionality of the selected BCSS. The first author coded the related data using a predefined form (which we all devised) for evaluating persuasive systems. The second author checked and commented on the resulting entries. We resolved any disparities through discussion. The procedure is similar to the expert-based inspection method, heuristic evaluation, that Jaspers (2009) describes.

\section{Findings}

Table 2 collectively presents the persuasive system features that we identified in the evaluated health behavior change support systems.

Table 2. Persuasive Features Identified in the Evaluated Behavior Change Support Systems

\begin{tabular}{|c|c|c|c|c|c|c|c|c|c|c|c|c|c|}
\hline Category & Feature & A1 & A2 & A3 & A4 & A5 & A6 & w1 & W2 & W3 & W4 & W5 & W6 \\
\hline \multirow{7}{*}{$\begin{array}{l}\text { Primary task } \\
\text { support }\end{array}$} & Reduction & $\checkmark$ & & $\checkmark$ & $\checkmark$ & $\checkmark$ & $\checkmark$ & $\checkmark$ & $\checkmark$ & $\checkmark$ & $\checkmark$ & $\checkmark$ & $\checkmark$ \\
\hline & Self-monitoring & $\checkmark$ & & $\checkmark$ & $\checkmark$ & $\checkmark$ & $\checkmark$ & $\checkmark$ & $\checkmark$ & $\checkmark$ & $\checkmark$ & $\checkmark$ & $\checkmark$ \\
\hline & Personalization & & $\checkmark$ & & $\checkmark$ & $\checkmark$ & & $\checkmark$ & $\checkmark$ & $\checkmark$ & $\checkmark$ & $\checkmark$ & $\checkmark$ \\
\hline & Rehearsal & $\checkmark$ & & $\checkmark$ & & $\checkmark$ & & $\checkmark$ & $\checkmark$ & $\checkmark$ & $\checkmark$ & $\checkmark$ & $\checkmark$ \\
\hline & Simulation & & & $\checkmark$ & & $\checkmark$ & & $\checkmark$ & $\checkmark$ & $\checkmark$ & $\checkmark$ & $\checkmark$ & $\checkmark$ \\
\hline & Tailoring & & & & & $\checkmark$ & & $\checkmark$ & $\checkmark$ & $\checkmark$ & $\checkmark$ & $\checkmark$ & $\checkmark$ \\
\hline & Tunneling & $\checkmark$ & $\checkmark$ & $\checkmark$ & & $\checkmark$ & & & & & & & \\
\hline \multirow{5}{*}{$\begin{array}{l}\text { Dialogue } \\
\text { support }\end{array}$} & Suggestion & $\checkmark$ & & $\checkmark$ & $\checkmark$ & $\checkmark$ & $\checkmark$ & $\checkmark$ & $\checkmark$ & $\checkmark$ & & $\checkmark$ & $\checkmark$ \\
\hline & Reminders & $\checkmark$ & & $\checkmark$ & $\checkmark$ & & & $\checkmark$ & $\checkmark$ & & & & $\checkmark$ \\
\hline & Social role & $\checkmark$ & & $\checkmark$ & & $\checkmark$ & $\checkmark$ & $\checkmark$ & & & & & \\
\hline & Praise & & & & $\checkmark$ & $\checkmark$ & & & $\checkmark$ & $\checkmark$ & & & \\
\hline & Rewards & & & & & & & & $\checkmark$ & $\checkmark$ & & & \\
\hline \multirow{7}{*}{$\begin{array}{l}\text { Credibility } \\
\text { support }\end{array}$} & Surface credibility & $\checkmark$ & $\checkmark$ & $\checkmark$ & $\checkmark$ & $\checkmark$ & $\checkmark$ & $\checkmark$ & $\checkmark$ & $\checkmark$ & $\checkmark$ & $\checkmark$ & $\checkmark$ \\
\hline & Trustworthiness & $\checkmark$ & $\checkmark$ & $\checkmark$ & $\checkmark$ & $\checkmark$ & $\checkmark$ & $\checkmark$ & $\checkmark$ & $\checkmark$ & $\checkmark$ & $\checkmark$ & $\checkmark$ \\
\hline & Expertise & $\checkmark$ & $\checkmark$ & $\checkmark$ & $\checkmark$ & $\checkmark$ & $\checkmark$ & $\checkmark$ & $\checkmark$ & $\checkmark$ & $\checkmark$ & & $\checkmark$ \\
\hline & Real-world feel & $\checkmark$ & $\checkmark$ & $\checkmark$ & & $\checkmark$ & $\checkmark$ & $\checkmark$ & $\checkmark$ & $\checkmark$ & $\checkmark$ & $\checkmark$ & $\checkmark$ \\
\hline & Verifiability & $\checkmark$ & & $\checkmark$ & $\checkmark$ & $\checkmark$ & $\checkmark$ & & & $\checkmark$ & & & $\checkmark$ \\
\hline & Authority & & $\checkmark$ & & & $\checkmark$ & $\checkmark$ & & & & & & $\checkmark$ \\
\hline & Third party endorsements & & & $\checkmark$ & $\checkmark$ & & & & & & & & $\checkmark$ \\
\hline \multirow{7}{*}{ Social support } & Normative influence & $\checkmark$ & $\checkmark$ & $\checkmark$ & $\checkmark$ & $\checkmark$ & $\checkmark$ & $\checkmark$ & $\checkmark$ & $\checkmark$ & $\checkmark$ & $\checkmark$ & $\checkmark$ \\
\hline & Social comparison & $\checkmark$ & & & $\checkmark$ & $\checkmark$ & & $\checkmark$ & $\checkmark$ & $\checkmark$ & $\checkmark$ & $\checkmark$ & $\checkmark$ \\
\hline & Social facilitation & $\checkmark$ & & & $\checkmark$ & $\checkmark$ & & $\checkmark$ & $\checkmark$ & $\checkmark$ & $\checkmark$ & $\checkmark$ & $\checkmark$ \\
\hline & Social learning & $\checkmark$ & & & $\checkmark$ & $\checkmark$ & & $\checkmark$ & $\checkmark$ & $\checkmark$ & $\checkmark$ & $\checkmark$ & $\checkmark$ \\
\hline & Recognition & & & & $\checkmark$ & & & & $\checkmark$ & $\checkmark$ & $\checkmark$ & $\checkmark$ & $\checkmark$ \\
\hline & Competition & & & & & & & $\checkmark$ & $\checkmark$ & $\checkmark$ & & & \\
\hline & Cooperation & $\checkmark$ & & & $\checkmark$ & $\checkmark$ & & & & & & & \\
\hline
\end{tabular}




\subsection{Primary Task Support}

Reduction means that the system reduces complex behavior into simple tasks, which helps users to perform the target behavior and, thus, lessens the individuals' cognitive burden. Reduction is important because a system that guides users through a process or an experience provides opportunities to persuade along the way. We identified reduction in 11 of the 12 evaluated BCSS. Example implementation: users are provided with an exercise plan based on their preferences and self-set goals.

A system keeping track of a user's performance or status supports in achieving one's goals. Not surprisingly, we found this self-monitoring functionality in 11 of the 12 assessed BCSS. Burke and colleagues (2011) state that self-monitoring is an essential feature of behavioral weight loss intervention programs. In their systematic review, they found that more frequent self-monitoring was consistently and significantly associated with weight loss compared to less frequent self-monitoring (Burke, Wang, \& Sevick, 2011). Additionally, in the context of Web-based alcohol interventions, researchers have found self-monitoring to be important (Bewick, 2010). Example implementation: a daily drink or calorie calculator; the user is able to review past performance from a chart.

A persuasive system may offer personalized content and services for its users. In order for the content to be personalized, the user has to disclose some personal information (e.g., through registration or by creating a personal profile.) The quality of Web personalization depends on how well the content generated by the personalization agent matches the preferences and interests of the user in a particular domain (Tam \& Ho, 2005). We found personalization in nine of the 12 evaluated BCSS. Example implementation: adding modules to a personal dashboard.

Tailoring the content to meet the potential needs, interests, personality, usage context, and/or other factors relevant to a user group is likely to increase a system's persuasiveness (Enwald \& Huotari, 2010; Lustria, Cortese, Noar, \& Glueckauf, 2009). We found tailoring, closely related to personalization, was in seven of the 12 BCSS. Example implementation: an activity feed based on "my groups".

Rehearsing a behavior, which we observed in nine out of the 12 BCSS, can enable people to change their attitudes or behavior in the real world. Example implementation: a video-based exercise builder.

Educating users about certain topics can leave a lasting impact that transfers to the real world. Enabling users to observe the link between the cause and its effect is regarded as simulation; we observed this feature in nine out of the 12 BCSS. Example implementation: a calculator showing how many calories a specific physical activity burns.

Tunneling, often intertwined with "reduction", may enhance the change process since the user is led through a predetermined sequence of steps and since the user receives the most appropriate content and particularly at a proper time (Danaher, McKay, \& Seeley, 2005). We found tunneling in four out of the 12 BCSS. Example implementation: "Get started": the user is given a guided tour of the key functionalities and components.

\subsection{Dialogue Support}

In the PSD model, computer-human dialogue support describes the key principles in keeping the user active and motivated in using the system and helping the user to perform the intended behavior. The principles in the computer-human dialogue support category are praise, rewards, reminders, suggestion, similarity, liking, and social role. Surprisingly, dialogue support was rather weak overall. See Table 2.

A system should provide the user with fitting suggestions at proper moments during the system use, such as "Please eat half of a plate vegetables". We found this kind of suggestion in 10 of the 12 BCSS under investigation ${ }^{1}$. A persuasive system should remind users of their target behavior during the intervention. A recent systematic review demonstrates that the using periodic prompts can be effective in behaviorchange interventions (Fry \& Neff, 2009). We found reminders in half of the BCSS (i.e., 6). Example implementation: a weekly email reminder.

Some of the BCSS used social roles, praise, and rewards. A system adopting a social role (e.g., doctor, teacher) may be more persuasive. Groom et al. (2009, p. 842) argue that, "When an interface features a computer-generated entity presenting explicit cues of identity or social agency, people's expectations of

${ }^{1}$ For discussion of the importance of timing, see, e.g., Räisänen, Oinas-Kukkonen, \& Pahnila (2008). 
predictable social performance are increased". We found a social role in five of the BCSS. Example implementation: "Ask Mary", with which the user is able to ask diet-related questions to a character called Mary.

A system could praise users via words, images, symbols, or sounds based on their behaviors (e.g., sending a message such as "Good job!"). By offering praise, the system can make users more open to persuasion. Furthermore, the system should reward the user for achieving, for example, self-set goals. Quite surprisingly, we found praise in only four of the BCSS and its logical companion, virtual rewards (see Berkovsky, Coombe, Freyne, Bhandari, \& Baghaei, 2010), in only two of the 12 BCSS. Example implementation: users are provided with virtual medals (e.g., bronze, silver, gold) based on their performance.

We do not include two other factors that are important to dialogue support—liking and similarity-because evaluating these factors is inherently subjective. An attractive system is likely to be more persuasive due to liking (Robins, Holmes, \& Stasbury, 2010; Tractinsky, Cokhavi, Kirschenbaum, \& Sharfi, 2006). Individuals are also more readily persuaded through systems that match their self-image in some meaningful way. For example, a system aimed at teenagers should employ youthful phrases and imagery. This principle is known as similarity (cf. social identity cues; Sillence, Briggs, Harris, \& Fishwick, 2006).

\subsection{Credibility Support}

Much research has focused on supporting users' perceptions of credibility-in particular via providing surface credibility and showing trustworthiness, expertise, and real-world feel in the systems. Credibility is indeed a persuasive element (Cugelman, Thelwall, \& Dawes, 2009; Tormala, Briñol, \& Petty, 2006; Wathen a\& Burkell, 2002). Harris, Sillence, and Briggs (2009) suggest that perhaps even seemingly superficial design elements of a system can influence responses to health-risk information. In their study, credibility cues affected engagement with the website and influenced subsequent health behavior and cognition. Lemire, Paré, Sicotte, and Harvey (2008) found that credibility had a significant impact on the frequency of individuals' Internet use for seeking personal health information.

Visual aesthetics play an important role in how users evaluate interactive systems (Cyr, Head, \& Larios, 2010; Tractinsky et al., 2006). Sillence and Briggs (2007) consider a staged model of trust in which visual appeal influences early decisions to reject or mistrust BCSS and credibility (and personalization) of information content influences the decision to select or trust them.

In our view, people initially assess system credibility based on an intuitive first-hand inspection. The related principle is called surface credibility. Based on our investigation, all of the evaluated BCSS appeared, at least to some extent, credible. However, half of them (6 out of 12) contained a variety of advertisements ("banners"), which one may consider disruptive and, thus, reduce the perceived surface credibility.

Trustworthiness is crucial: users will engage with systems they perceive trustworthy and navigate away from those they mistrust (Cugelman et al., 2009; Sillence et al., 2006). A trustworthy system provides truthful, fair, and unbiased information. All of the investigated systems conveyed trustworthiness. Almost all of the evaluated BCSS, 11 out of 12, provided information demonstrating knowledge, experience, and competence. The related principle is called expertise. Example implementation: an extensive nutritionist Q\&A section.

A persuasive system should provide information about (and means to communicate with) the organization and/or actual people behind its content and services. This feature is called real-world feel, which we found in 11 of the 12 BCSS. Gefen and Straub (2004) argue that the perception of social presence increases online trust. In a similar vein, Rains and Karmikel (2009) suggest that including structural features such as the organization's physical address, privacy policy statement, and third-party endorsements (Beldad, de Jong, \& Proudfoot, 2010) may be especially important in determining the credibility of the system as perceived by users. Seven of the BCSS provided means to verify the accuracy of the presented guidance. Some of the systems (4 out of 12) also strongly referred to authorities (e.g., by linking to statements or norms by an authoritative health institute) or used third-party endorsements (3 out of 12 BCSS). 


\subsection{Social Support}

According to Uchino (2006), social support may refer to aspects of the social network (groups, familial ties), specific behaviors (e.g., emotional or informational support), or our perceived availability of support resources that may be shaped early in life.

Hardiker and Grant (2010) consider social computing (e.g., online discussion and support groups) as "providing a safe, flexible and personal environment in which to share experiences and responsibility, foster a sense of belonging, offer empathy and support and gain reassurance" (p. 9). They suggest that active engagement with social computing seems to be the most advantageous (Hardiker \& Grant, 2010). According to Kreps and Neuhauser (2010), social network applications are ideally suited for connecting social networks for personally promoting health. Barak, Boniel-Nissim, and Suler (2008) contend that online support fosters well-being, a sense of control, self-confidence, feelings of more independence, social interactions, and improved feelings. Thus, participating in an online support group could foster personal empowerment, which is necessary for dealing with specific conditions of distress (Barak et al., 2008). Bennett and Glasgow (2009) claim that no examples of trial designs exist to enable a systematic investigation of the potential benefits of social networking.

In the PSD model, the social support category describes how to design the system so that it motivates users by leveraging social influence. The model operates with the following persuasion techniques: social learning, social comparison, normative influence, social facilitation, cooperation, compensation, and recognition. The social learning principle (found in 9 out of the 12 BCSS) means that an individual may be more motivated to perform a target behavior if the individual can observe others performing the behavior while using the system. A closely related principle is social comparison (observed in 9 out of the 12 BCSS); users may be more motivated to carry out the target behavior if they can compare their performance with others'. Social facilitation (observed in 9 out of the 12 evaluated systems) allows users to observe others performing the behavior or be observed by others. In all instances, social learning, comparison, and facilitation were jointly implemented on par with normative influence. All 12 evaluated BCSS leveraged normative influence.

Half of the investigated systems (6 out of 12) offered public recognition for an individual or a group. Few BCSS provided users with opportunities for competition (observed in 3 out of the 12 BCSS) or cooperation (identified in 3 out of the 12 systems).

\section{Discussion}

Of the 12 Web-based health behavior change support systems included in the study, half aimed to reduce individuals' alcohol consumption, while half aimed at personal weight loss and maintenance. They used the primary task support features relatively often: reduction and self-monitoring were the most common principles to support accomplishing users' primary task. This is an encouraging finding since reduction and self-monitoring can be considered key elements for primary task support. We can reasonably assume that different approaches are needed for different kinds of user groups. Tailoring was used to serve the needs of different user groups but not to the extent we expected based on previous literature (Krebs et al., 2010). In our view, without at least some level of tailoring, the systems are targeted for too broad an audience.

The BCSS only modestly took advantage of opportunities to enhance computer-human dialogue. Leveraging reminders was the most common way to enhance the system-to-user dialogue, whereas virtual rewards were rarely used despite their large potential (Berkovsky et al., 2010; Harjumaa, Segerståhl, \& Oinas-Kukkonen, 2009). Naturally, the role of reminders and rewards may vary across problem domains.

Credibility issues are crucial in website engagement because users will engage with websites they perceive as credible and navigate away from those they do not perceive as credible. Based on our analysis of the systems, much of the persuasive design efforts thus far have been devoted to demonstrating the credibility of the Web-based interventions.

The prevalence of social support in the evaluated interventions is propitious. In anonymous online support groups, the participants may overcome the feeling of being stigmatized because the participants can choose to remain anonymous (or choose a nickname) and, thus, non-identifiable. Moreover, in online groups, time and location are no longer obstacles for active group participation. However, many issues 
still need to be resolved about the type of online support (e.g., whether it should be expert-led vs. userdriven, moderated vs. non-moderated, synchronous vs. asynchronous, and open access vs. restricted access).

Analyzing persuasive design is a challenging task. When conducting such an analysis, potential bias lies in interpreting the features. Thus, we omitted two highly subjective features from the analysis: liking and similarity. Some of the features are intertwined (e.g., social learning/comparison/facilitation) and are, thus, rather difficult to analyze. In addition, regardless of its wide coverage, the PSD model is not meant to be an exhaustive list of persuasive features, and new persuasion techniques may be identified in the future. The PSD model has been built in such a manner that it may evolve, but, even now, it is an important tool for any health behavior change system researcher and developer.

Another limitation is that the BCSS we analyzed represent only a small fraction of those currently available for users/consumers/patients. Nevertheless, we actually used and interacted with the BCSS for at least a one-month period each so the analysis was not based solely on superficial perceptions. However, as Sillence and Briggs (2007) mention, a related caveat is that users/consumers may still want different things than experts.

\section{Conclusion}

In this study, we extracted and analyzed persuasive system features of Web-based health behavior change support systems. The findings suggest that such systems, despite being developed with behavior change in mind, have room for improvement in terms of fulfilling their persuasive potential. We agree with other researchers (Consolvo et al., 2009; Hardiker \& Grant, 2010; Kreps \& Neuhauser, 2010; Sillence \& Briggs, 2007) that design issues deserve more attention because they have real implications. Nevertheless, we do not imply that the mere presence of persuasive design features is sufficient, nor do we want to take a technologically deterministic stance. Evidently, developing Web-based health behavior change support systems is a highly elaborate and multifaceted process. In order for widespread adoption, dissemination, and, most importantly, extended use of such systems to take place, we need to investigate not only how the interventions affect individuals but also how individuals interact with technology and each other via them (Atienza, Hesse, Gustafson, \& Croyle, 2010). Furthermore, designing, implementing, and evaluating features that participants find attractive and captivating should be a priority. This type of knowledge may assist in deploying interventions that engage and retain large amounts of individuals, which can potentially enhance population health and well-being and, thus, be of significant public health value.

\section{Acknowledgments}

This research was conducted in the OASIS research group, which is supported by the Martti Ahtisaari Institute, University of Oulu. 


\section{References}

Ajzen, I. (1991). The theory of planned behavior. Organizational Behavior and Human Decision Processes, 50(2), 179-211.

Atienza, A. A., Hesse, B. W., Gustafson, D. H., \& Croyle, R. T. (2010). E-health research and patientcentered care examining theory, methods, and application. American Journal of Preventive Medicine, 38(1), 85-88.

Barak, A., Boniel-Nissim, M., \& Suler, J. (2008). Fostering empowerment in online support groups. Computers in Human Behavior, 24(5), 1867-1883.

Barak, A., Klein, B., \& Proudfoot, J. G. (2009). Defining Internet-supported therapeutic interventions. Annals of Behavioral Medicine, 38(1), 4-17.

Beldad, A., de Jong, M., \& Steehouder, M. (2010). How shall I trust the faceless and the intangible? A literature review on the antecedents of online trust. Computers in Human Behavior, 26(5), 857869.

Bennett, G. G., \& Glasgow, R. E. (2009). The delivery of public health interventions via the Internet: Actualizing their potential. Annual Review of Public Health, 30, 273-292.

Berkovsky, S., Coombe, M., Freyne, J., Bhandari, D., \& Baghaei, N. (2010). Physical activity motivating games: Virtual rewards for real activity. In Proceedings of the 28th International Conference on Human Factors in Computing Systems (pp. 243-252).

Bewick, B. M. (2010). Providing Web-based feedback and social norms information to reduce student alcohol intake: A multisite investigation. Journal of Medical Internet Research, 12(5), e59.

Bewick, B. M., Trusler, K., Barkham, M., Hill, A. J., Cahill, J., \& Mulhern, B. (2008). The effectiveness of Web-based interventions designed to decrease alcohol consumption-a systematic review. Preventive Medicine, 47(1), 17-26.

Briñol, P., \& Petty, R. E. (2009). Persuasion: Insights from the self-validation hypothesis. Advances in Experimental Social Psychology, 41, 69-118.

Burke, L. E., Wang, J., \& Sevick, M. A. (2011). Self-monitoring in weight loss: A systematic review of the literature. Journal of the American Dietetic Association, 111(1), 92-102.

Consolvo, S., McDonald, D. W., \& Landay, J. A. (2009). Theory-driven design strategies for technologies that support behavior change in everyday life. In Proceedings of the 27th International Conference on Human Factors in Computing Systems (pp. 405-414).

Cugelman, B., Thelwall, M., \& Dawes, P. L. (2009). Dimensions of web site credibility and their relation to active trust and behavioural impact. Communications of the Association for Information Systems, 24, 455-472.

Cyr, D., Head, M., \& Larios, H. (2010). Colour appeal in website design within and across cultures: A multi-method evaluation. International Journal of Human-Computer Studies, 68(1-2), 1-21.

Danaher, B. G., McKay, H. G., \& Seeley, J. R. (2005). The information architecture of behavior change websites. Journal of Medical Internet Research, 7(2), e12.

Enwald, H. P., \& Huotari, M. L. (2010). Preventing the obesity epidemic by second generation tailored health communication: An interdisciplinary review. Journal of Medical Internet Research, 12(2), e24.

Eysenbach, G. (2005). The law of attrition. Journal of Medical Internet Research, 7(1), e11.

Fogg, B. J. (2003). Persuasive technology: Using computers to change what we think and do. Amsterdam: Morgan Kaufmann.

Fry, J. P., \& Neff, R. A. (2009). Periodic prompts and reminders in health promotion and health behavior interventions: Systematic review. Journal of Medical Internet Research, 11(2), e16.

Gefen, D., \& Straub, D. W. (2004). Consumer trust in B2C e-commerce and the importance of social presence: Experiments in e-products and e-services. Omega, 32(6), 407-424. 
Glanz, K., \& Bishop, D. B. (2010). The role of behavioral science theory in development and implementation of public health interventions. Annual Review of Public Health, 31, 399-418.

Groom, V., Nass, C., Chen, T., Nielsen, A., Scarborough, J. K., \& Robles, E. (2009). Evaluating the effects of behavioral realism in embodied agents. International Journal of Human-Computer Studies, 67(10), 842-849.

Hardiker, N. R., \& Grant, M. J. (2010). Factors that influence public engagement with eHealth: A literature review. International Journal of Medical Informatics, 80(1), 1-12.

Harjumaa, M., Segerståhl, K., \& Oinas-Kukkonen, H. (2009). Understanding persuasive software functionality in practice: A field trial of polar FT60. In Proceedings of the 4th International Conference on Persuasive Technology (pp. 1-9).

Harris, P. R., Sillence, E., \& Briggs, P. (2009). The effect of credibility-related design cues on responses to a Web-based message about the breast cancer risks from alcohol: Randomized controlled trial. Journal of Medical Internet Research, 11(3), e37.

Harvey-Berino, J., West, D., Krukowski, R., Prewitt, E., VanBiervliet, A., Ashikaga, T., \& Skelly, J. (2010). Internet delivered behavioral obesity treatment. Preventive Medicine, 51(2), 123-128.

Hurling, R., Catt, M., De Boni, M., Fairley, B. W., Hurst, T., Murray, P., Richardson, A., \& Sodhi, J. S. (2007). Using Internet and mobile phone technology to deliver an automated physical activity program: Randomized controlled trial. Journal of Medical Internet Research, 9(2)

Jaspers, M. W. M. (2009). A comparison of usability methods for testing interactive health technologies: Methodological aspects and empirical evidence. International Journal of Medical Informatics, 78(5), 340-353.

Kelders, S. M., Kok, R. N., Ossebaard H. C., Van Gemert-Pijnen J. E. W. C. (2012) Persuasive system design does matter: a systematic review of adherence to Web-based interventions. Journal of Medical Internet Research, 14(6), e152.

Krebs, P., Prochaska, J. O., \& Rossi, J. S. (2010). A meta-analysis of computer-tailored interventions for health behavior change, Preventive Medicine, 51(3-4), 214-221.

Kreps, G. L., \& Neuhauser, L. (2010). New directions in eHealth communication: Opportunities and challenges. Patient Education and Counseling, 78(3), 329-336.

Krukowski, R. A., Harvey-Berino, J., Ashikaga, T., Thomas, C. S., \& Micco, N. (2008). Internet-based weight control: The relationship between Web features and weight loss. Telemedicine Journal and E-Health: The Official Journal of the American Telemedicine Association, 14(8), 775-782.

Lemire, M., Paré, G., Sicotte, C., \& Harvey, C. (2008). Determinants of Internet use as a preferred source of information on personal health. International Journal of Medical Informatics, 77(11), 723-734.

Locke, E. A., \& Latham, G. P. (2002). Building a practically useful theory of goal setting and task motivation: A 35-year odyssey. American Psychologist, 57(9), 705-717.

Lustria, M. L. A., Cortese, J., Noar, S. M., \& Glueckauf, R. L. (2009). Computer-tailored health interventions delivered over the Web: Review and analysis of key components. Patient Education and Counseling, 74(2), 156-173.

Neve, M., Morgan, P., Jones, P., \& Collins, C. (2009). Effectiveness of Web-based interventions in achieving weight loss and weight loss maintenance in overweight and obese adults: A systematic review with meta-analysis. Obesity Reviews, 11(4), 306-321.

Oinas-Kukkonen, H. (2010) Behavior change support systems: A research model and agenda. Lecture Notes in Computer Science, 6137, 4-14.

Oinas-Kukkonen, H. (2013). A foundation for the study of behavior change support systems. Personal and Ubiquitous Computing, 17(6), 1223-1235.

Oinas-Kukkonen, H., \& Harjumaa, M. (2008). A systematic framework for designing and evaluating persuasive systems. Lecture Notes in Computer Science, 5033, 164-176. 
Oinas-Kukkonen, H., \& Harjumaa, M. (2009). Persuasive systems design: Key issues, process model, and system features. Communications of the Association for Information Systems, 24, 485-500.

Petty, R. E., \& Cacioppo, J. T. (1986). The elaboration likelihood model of persuasion. Advances in Experimental Social Psychology, 19, 123-205.

Portnoy, D. B., Scott-Sheldon, L. A. J., Johnson, B. T., \& Carey, M. P. (2008). Computer-delivered interventions for health promotion and behavioral risk reduction: A meta-analysis of 75 randomized controlled trials, 1988-2007. Preventive Medicine, 47(1), 3-16.

Rains, S. A., \& Karmikel, C. D. (2009). Health information-seeking and perceptions of website credibility: Examining Web-use orientation, message characteristics, and structural features of websites. Computers in Human Behavior, 25(2), 544-553.

Robins, D., Holmes, J., \& Stansbury, M. (2010). Consumer health information on the Web: The relationship of visual design and perceptions of credibility. Journal of the American Society for Information Science and Technology, 61(1), 13-29.

Räisänen T., Oinas-Kukkonen H. \& Pahnila S. (2008) Finding kairos in quitting smoking: Smokers' perceptions of warning pictures. Lecture Notes in Computer Science, 5033, 263-266.

Shahab, L., \& McEwen, A. (2009). Online support for smoking cessation: A systematic review of the literature. Addiction, 104(11), 1792-1804.

Sillence, E., \& Briggs, P. (2007). Please advise: Using the Internet for health and financial advice. Computers in Human Behavior, 23(1), 727-748.

Sillence, E., Briggs, P., Harris, P., \& Fishwick, L. (2006). A framework for understanding trust factors in Web-based health advice. International Journal of Human-Computer Studies, 64(8), 697-713.

Tam, K. Y., \& Ho, S. Y. (2005). Web personalization as a persuasion strategy: An elaboration likelihood model perspective. Information Systems Research, 16(3), 271-291.

Tate, D. F., Jackvony, E. H., \& Wing, R. R. (2003). Effects of Internet behavioral counseling on weight loss in adults at risk for type 2 diabetes: A randomized trial. JAMA, 289(14), 1833-1836.

Tormala, Z. L., Briñol, P., \& Petty, R. E. (2006). When credibility attacks: The reverse impact of source credibility on persuasion. Journal of Experimental Social Psychology, 42(5), 684-691.

Tractinsky, N., Cokhavi, A., Kirschenbaum, M., \& Sharfi, T. (2006). Evaluating the consistency of immediate aesthetic perceptions of web pages. International Journal of Human-Computer Studies, 64(11), 1071-1083.

Uchino, B. N. (2006). Social support and health: A review of physiological processes potentially underlying links to disease outcomes. Journal of Behavioral Medicine, 29(4), 377-387.

van Straten, A., Cuijpers, P., \& Smits, N. (2008). Effectiveness of a Web-based self-help intervention for symptoms of depression, anxiety, and stress: Randomized controlled trial. Journal of Medical Internet Research, 10(1), e7.

Wathen, C. N., \& Burkell, J. (2002). Believe it or not: Factors influencing credibility on the Web. Journal of the American Society for Information Science and Technology, 53(2), 134-144.

Webb, T. L., Joseph, J., Yardley, L., \& Michie, S. (2010). Using the Internet to promote health behavior change: A systematic review and meta-analysis of the impact of theoretical basis, use of behavior change techniques, and mode of delivery on efficacy. Journal of Medical Internet Research, 12(1), e4. 


\section{Appendix}

Table A1. Persuasive System Feature Guide for Evaluating HBCSS (Adapted from Oinas-Kukkonen \& Harjumaa, 2009)

\begin{tabular}{|c|c|c|c|}
\hline Category & Feature & Description & Example implementation \\
\hline \multirow{7}{*}{$\begin{array}{l}\text { Primary task } \\
\text { support }\end{array}$} & Reduction & $\begin{array}{l}\text { The system reduces effort that users } \\
\text { expend with regard to performing their } \\
\text { target behavior. }\end{array}$ & $\begin{array}{l}\text { The user is provided with an exercise } \\
\text { plan / diet based on her/his } \\
\text { preferences and self-set goals. }\end{array}$ \\
\hline & Tunneling & $\begin{array}{l}\text { The system guides users in the attitude } \\
\text { change process by providing means for } \\
\text { action that brings them closer to the } \\
\text { target behavior. }\end{array}$ & $\begin{array}{l}\text { The user is given a guided tour of the } \\
\text { key functionalities and components of } \\
\text { the system. }\end{array}$ \\
\hline & Self-monitoring & $\begin{array}{l}\text { The system provides means for users } \\
\text { to track their behavior, performance or } \\
\text { status. }\end{array}$ & $\begin{array}{l}\text { The user is able to review past } \\
\text { performance from a chart or a graph. }\end{array}$ \\
\hline & Tailoring & $\begin{array}{l}\text { The system provides tailored content } \\
\text { for distinct user groups. }\end{array}$ & $\begin{array}{l}\text { Different content for beginners and } \\
\text { advanced users; women and men }\end{array}$ \\
\hline & Personalization & $\begin{array}{l}\text { The system offers personalized content } \\
\text { and services for the users. }\end{array}$ & $\begin{array}{l}\text { The system and its content is } \\
\text { personalized based on user's } \\
\text { preferences and other known } \\
\text { variables e.g. name, gender, age, } \\
\text { location, language. }\end{array}$ \\
\hline & Rehearsal & $\begin{array}{l}\text { The system provides means for } \\
\text { rehearsing target behavior. }\end{array}$ & $\begin{array}{l}\text { A video-based exercise builder; A } \\
\text { guided breathing exercise. }\end{array}$ \\
\hline & Simulation & $\begin{array}{l}\text { The system provides means for } \\
\text { observing the cause and effect with } \\
\text { regard to users' behavior. }\end{array}$ & $\begin{array}{l}\text { A calculator showing how many } \\
\text { calories a specific physical activity } \\
\text { burns; overall health score based on } \\
\text { user's aggregated personal health } \\
\text { data. }\end{array}$ \\
\hline \multirow{7}{*}{$\begin{array}{l}\text { Dialogue } \\
\text { support }\end{array}$} & Reminders & $\begin{array}{l}\text { The system reminds users of their } \\
\text { target behavior during the use of the } \\
\text { system. }\end{array}$ & $\begin{array}{l}\text { Automatized / event-triggered / user } \\
\text { customizable reminders via e.g. email } \\
\text { / SMS / screen prompt }\end{array}$ \\
\hline & Suggestion & $\begin{array}{l}\text { The system suggests that users carry } \\
\text { out behaviors during the system use } \\
\text { process. }\end{array}$ & $\begin{array}{l}\text { Suggesting the user to increase } \\
\text { vegetable and fruit intake during the } \\
\text { day. }\end{array}$ \\
\hline & Social role & The system adopts a social role. & $\begin{array}{l}\text { Embodied conversational agent } \\
\text { offering advice and suggestions. }\end{array}$ \\
\hline & Praise & $\begin{array}{l}\text { The system praises via words, images, } \\
\text { symbols, or sounds as a way to } \\
\text { provide positive feedback. }\end{array}$ & $\begin{array}{l}\text { Automated prompt complimenting the } \\
\text { user for reaching a certain goal. }\end{array}$ \\
\hline & Rewards & $\begin{array}{l}\text { The system gives credit for performing } \\
\text { the target behavior. }\end{array}$ & $\begin{array}{l}\text { The user is provided with virtual } \\
\text { medals, trophies or badges based } \\
\text { on her/his performance. }\end{array}$ \\
\hline & Similarity & $\begin{array}{l}\text { The system imitates its users in some } \\
\text { specific way }\end{array}$ & $\begin{array}{l}\text { Youthful graphics are used in a } \\
\text { system motivating teenagers to } \\
\text { exercise. }\end{array}$ \\
\hline & Liking & $\begin{array}{l}\text { The system has a look and feel that } \\
\text { appeals to its users. }\end{array}$ & $\begin{array}{l}\text { Likeable visual characters, positive } \\
\text { tone in text and graphics }\end{array}$ \\
\hline
\end{tabular}


Table A1. Persuasive System Feature Guide for Evaluating HBCSS (Adapted from Oinas-Kukkonen \& Harjumaa, 2009)

\begin{tabular}{|c|c|c|c|}
\hline \multirow{7}{*}{$\begin{array}{l}\text { Credibility } \\
\text { support }\end{array}$} & Surface credibility & $\begin{array}{l}\text { The system has a competent look and } \\
\text { feel. The visual design should reflect } \\
\text { the content and the context. }\end{array}$ & $\begin{array}{l}\text { Clear and consistent visual layout and } \\
\text { graphics, images and typography; no } \\
\text { typos / grammatical errors; no } \\
\text { excessive marketing. }\end{array}$ \\
\hline & Trustworthiness & $\begin{array}{l}\text { The system provides information that is } \\
\text { truthful, fair and unbiased. The system } \\
\text { must not exploit private user data. }\end{array}$ & $\begin{array}{l}\text { The provided information } \\
\text { demonstrating knowledge, experience, } \\
\text { and competence. }\end{array}$ \\
\hline & Expertise & $\begin{array}{l}\text { The system provides information } \\
\text { demonstrating knowledge, experience, } \\
\text { and competence. }\end{array}$ & An extensive nutritionist Q\&A section. \\
\hline & Real-world feel & $\begin{array}{l}\text { The system provides information of the } \\
\text { organization and/or actual people } \\
\text { behind its content and services. }\end{array}$ & $\begin{array}{l}\text { The system provides means to contact } \\
\text { the developer via e-mail address; } \\
\text { physical address; }\end{array}$ \\
\hline & Verifiability & $\begin{array}{l}\text { The system provides means to verify } \\
\text { the accuracy of website content via } \\
\text { outside sources. }\end{array}$ & $\begin{array}{l}\text { Providing links to external resources } \\
\text { and references to scientific } \\
\text { publications. }\end{array}$ \\
\hline & Authority & $\begin{array}{l}\text { The system refers to people in the role } \\
\text { of authority. }\end{array}$ & $\begin{array}{l}\text { External linking to statements or } \\
\text { norms by an authoritative health } \\
\text { institute. }\end{array}$ \\
\hline & $\begin{array}{l}\text { Third party } \\
\text { endorsements }\end{array}$ & $\begin{array}{l}\text { The system provides endorsements } \\
\text { from respected sources. }\end{array}$ & $\begin{array}{l}\text { An award, certificate, or a } \\
\text { recommendation from an authoritative } \\
\text { source. }\end{array}$ \\
\hline \multirow{7}{*}{$\begin{array}{l}\text { Social } \\
\text { support }\end{array}$} & Normative influence & $\begin{array}{l}\text { The system provides means for } \\
\text { gathering together people who have } \\
\text { the same goal and make them feel } \\
\text { norms. }\end{array}$ & $\begin{array}{l}\text { The users can share their information } \\
\text { with similar users, and view } \\
\text { information from similar users. }\end{array}$ \\
\hline & Social comparison & $\begin{array}{l}\text { The system provides means for } \\
\text { comparing performance with the } \\
\text { performance of other users. }\end{array}$ & $\begin{array}{l}\text { Users can share and compare their } \\
\text { goals and progress via social } \\
\text { networking applications. }\end{array}$ \\
\hline & Social facilitation & $\begin{array}{l}\text { The system provides means for } \\
\text { discerning other users who are } \\
\text { performing the behavior. }\end{array}$ & $\begin{array}{l}\text { Users can recognize how many others } \\
\text { are at the same location. }\end{array}$ \\
\hline & Social learning & $\begin{array}{l}\text { The system provides means to observe } \\
\text { other users who are performing their } \\
\text { target behaviors and to see the } \\
\text { outcomes of their behavior. }\end{array}$ & $\begin{array}{l}\text { Users are able to observe each other } \\
\text { through a shared weight loss journal. }\end{array}$ \\
\hline & Recognition & $\begin{array}{l}\text { The system provides public recognition } \\
\text { for users who perform their target } \\
\text { behavior. }\end{array}$ & $\begin{array}{l}\text { Personal stories of the people who } \\
\text { have succeeded in their target } \\
\text { behavior / goal are presented to other } \\
\text { users. }\end{array}$ \\
\hline & Competition & $\begin{array}{l}\text { The system provides means for } \\
\text { competing with other users. }\end{array}$ & $\begin{array}{l}\text { Stop smoking for a month and win a } \\
\text { prize. }\end{array}$ \\
\hline & Cooperation & $\begin{array}{l}\text { The system provides means for co- } \\
\text { operation. }\end{array}$ & $\begin{array}{l}\text { Users can tag and share locations } \\
\text { with other users. }\end{array}$ \\
\hline
\end{tabular}




\begin{abstract}
About the Authors
Tuomas Lehto holds a PhD in Information Systems from University of Oulu, Finland. His research interests include persuasive systems design, consumer health informatics, health behavior change support systems, Web- and mobile-based information systems. Currently, he is on leave from academia and is working for Duodecim Medical Publications (Helsinki, Finland) as a research and development manager. In his work with medical professionals, he is responsible for researching and developing various e-health services for citizens.

Harri Oinas-Kukkonen is Professor of information systems at the Faculty of Information Technology and Electrical Engineering in the University of Oulu, Finland. His current research interests in the areas of human-computer interaction and health informatics include user behavior, behavior change, persuasive design, social and organizational knowledge, innovation creation, and the next generation of the Web. Recently, he co-authored a book "Humanizing the Web: Change and Social Innovation" (Palgrave MacMillan, 2013). The book discusses the Web's future and how it continues to change businesses, software design, the way we perceive people, and the skills required of us, and it positions this transformation in the developments of international business and management.
\end{abstract}

Copyright $\odot 2015$ by the Association for Information Systems. Permission to make digital or hard copies of all or part of this work for personal or classroom use is granted without fee provided that copies are not made or distributed for profit or commercial advantage and that copies bear this notice and full citation on the first page. Copyright for components of this work owned by others than the Association for Information Systems must be honored. Abstracting with credit is permitted. To copy otherwise, to republish, to post on servers, or to redistribute to lists requires prior specific permission and/or fee. Request permission to publish from: AIS Administrative Office, P.O. Box 2712 Atlanta, GA, 30301-2712 Attn: Reprints or via email from publications@aisnet.org. 


\section{(1) \\ $T_{\text {rensarations on }}$ \\ $H_{\text {wman }}-C_{\text {omputer }} \boldsymbol{I}_{\text {nteraction }}$}

\section{Editors-in-Chief}

Dennis Galletta, U. of Pittsburgh, USA http://thci.aisnet.org/

Joe Valacich, U. of Arizona, USA

\section{Advisory Board}

Izak Benbasat
U. of British Columbia, Canada

Jenny Preece

U. of Maryland, USA

Jane Webster

Queen's U., Canada

\author{
John M. Carroll \\ Penn State U., USA \\ Gavriel Salvendy \\ Purdue U., USA, \& Tsinghua U., China \\ K.K. Wei \\ City U. of Hong Kong, China
}

\author{
Phillip Ein-Dor \\ Tel-Aviv U., Israel \\ Ben Shneiderman \\ U. of Maryland, USA \\ Ping Zhang \\ Syracuse University, USA
}

\section{Senior Editor Board}

$\begin{aligned} & \text { Torkil Clemmensen } \\ & \text { Copenhagen Business School, } \\ & \text { Denmark }\end{aligned}$
Mohamed Khalifa
U. Wollongong in Dubai., UAE
Fiona Fui-Hoon Nah
U. of Nebraska-Lincoln, USA
Jason Thatcher
Clemson U., USA

\begin{tabular}{l|l}
$\begin{array}{l}\text { Fred Davis } \\
\text { U. of Arkansas, USA }\end{array}$ \\
$\begin{array}{l}\text { Jinwoo Kim } \\
\text { Yonsei U., Korea }\end{array}$ \\
\hline $\begin{array}{l}\text { Lorne Olfman } \\
\text { Claremont Graduate U., USA }\end{array}$ \\
\hline $\begin{array}{l}\text { Noam Tractinsky } \\
\text { Ben-Gurion U. of the Negev, Israel }\end{array}$
\end{tabular}

Traci Hess

U. of Massachusetts Amherst, USA

Paul Benjamin Lowry

City U. of Hong Kong

Kar Yan Tam

Hong Kong U. of Science \&

Technology, China

Viswanath Venkatesh

U. of Arkansas, USA
Shuk Ying (Susanna) Ho

Australian National U., Australia

Anne Massey

Indiana U., USA

Dov Te'eni

Tel-Aviv U., Israel

Mun Yi

Korea Advanced Ins. of Sci. \&

Tech, Korea

\section{Editorial Board}

\begin{tabular}{l|l}
\hline $\begin{array}{l}\text { Miguel Aguirre-Urreta } \\
\text { DePaul U., USA }\end{array}$ & $\begin{array}{l}\text { Michel Avital } \\
\text { Copenhagen Business School, } \\
\text { Denmark }\end{array}$ \\
\hline $\begin{array}{l}\text { Michael Davern } \\
\text { U. of Melbourne, Australia }\end{array}$ & $\begin{array}{l}\text { Alexandra Durcikova } \\
\text { U. of Oklahoma }\end{array}$ \\
\hline $\begin{array}{l}\text { Jennifer Gerow } \\
\text { Virginia Military Institute, USA }\end{array}$ & $\begin{array}{l}\text { Suparna Goswami } \\
\text { Technische U.München, Germany }\end{array}$ \\
\hline $\begin{array}{l}\text { Netta livari } \\
\text { Oulu U., Finland }\end{array}$ & $\begin{array}{l}\text { Zhenhui Jack Jiang } \\
\text { National U. of Singapore, } \\
\text { Singapore }\end{array}$ \\
\hline $\begin{array}{l}\text { Sherrie Komiak } \\
\text { Memorial U. of Newfoundland, }\end{array}$ & $\begin{array}{l}\text { Na Li } \\
\text { Banada }\end{array}$ \\
\hline $\begin{array}{l}\text { Greg D. Moody } \\
\text { U. of Nevada, Las Vegas, USA }\end{array}$ & $\begin{array}{l}\text { Robert F. Otondo } \\
\text { Mississippi State U., USA }\end{array}$ \\
\hline $\begin{array}{l}\text { Rene Riedl } \\
\text { Johannes Kepler U. Linz, Austria }\end{array}$ & $\begin{array}{l}\text { Khawaja Saeed } \\
\text { Wichita State U., USA }\end{array}$ \\
\hline $\begin{array}{l}\text { Stefan Smolnik } \\
\text { European Business School, } \\
\text { Germany }\end{array}$ & $\begin{array}{l}\text { Jeff Stanton } \\
\text { Syracuse U., USA }\end{array}$ \\
\hline $\begin{array}{l}\text { Ozgur Turetken } \\
\text { Ryerson U., Canada } \\
\text { Reiyun Zuo }\end{array}$ & $\begin{array}{l}\text { Carina de Villiers } \\
\text { U. of Pretoria, South Africa }\end{array}$ \\
\hline
\end{tabular}

\begin{tabular}{l|l}
$\begin{array}{l}\text { Hock Chuan Chan } \\
\text { National U. of Singapore, } \\
\text { Singapore }\end{array}$ & $\begin{array}{l}\text { Christy M.K. Cheung } \\
\text { Hong Kong Baptist University, } \\
\text { China }\end{array}$ \\
\hline $\begin{array}{l}\text { Xiaowen Fang } \\
\text { DePaul University }\end{array}$ & $\begin{array}{l}\text { Matt Germonprez } \\
\text { U. of Wisconsin Eau Claire, USA }\end{array}$ \\
\hline $\begin{array}{l}\text { Khaled Hassanein } \\
\text { McMaster U., Canada }\end{array}$ & $\begin{array}{l}\text { Milena Head } \\
\text { McMaster U., Canada }\end{array}$ \\
\hline $\begin{array}{l}\text { Richard Johnson } \\
\text { SUNY at Albany, USA }\end{array}$ & $\begin{array}{l}\text { Weiling Ke } \\
\text { Clarkson U., USA }\end{array}$ \\
\hline $\begin{array}{l}\text { Ji-Ye Mao } \\
\text { Renmin U., China }\end{array}$ & $\begin{array}{l}\text { Scott McCoy } \\
\text { College of William and Mary, USA }\end{array}$ \\
\hline $\begin{array}{l}\text { Lingyun Qiu } \\
\text { Peking U., China }\end{array}$ & $\begin{array}{l}\text { Sheizaf Rafaeli } \\
\text { U. of Haifa, Israel }\end{array}$ \\
\hline $\begin{array}{l}\text { Shu Schiller } \\
\text { Wright State U., USA }\end{array}$ & $\begin{array}{l}\text { Hong Sheng } \\
\text { Missouri U. of Science and } \\
\text { Technology, USA }\end{array}$ \\
\hline $\begin{array}{l}\text { Heshan Sun } \\
\text { Clemson U., USA }\end{array}$ & $\begin{array}{l}\text { Horst Treiblmaier } \\
\text { Purdue U., USA }\end{array}$ \\
\hline $\begin{array}{l}\text { Fahri Yetim } \\
\text { FOM U. of Applied Sciences, } \\
\text { Germany }\end{array}$ & $\begin{array}{l}\text { Fudan U., China } \\
\text { Cheng Zhang }\end{array}$ \\
\hline
\end{tabular}

Renmin U., China

\section{Managing Editors}

Jeff Jenkins, Brigham Young U., USA

\section{SIGHCI Chairs}

2001-2004: Ping Zhang

2007-2008: Weiyin Hong

2011-2012: Dianne Cyr
2004-2005: Fiona Fui-Hoon Nah

2008-2009: Eleanor Loiacono

2012-2013: Soussan Djamasbi http://sigs.aisnet.org/sighci

2005-2006: Scott McCoy

2006-2007: Traci Hess

2009-2010: Khawaja Saeed

2010-2011: Dezhi Wu 